JUN 17 T995

Sta. 3 ENGINEERING DATA TRANSMITTAL.

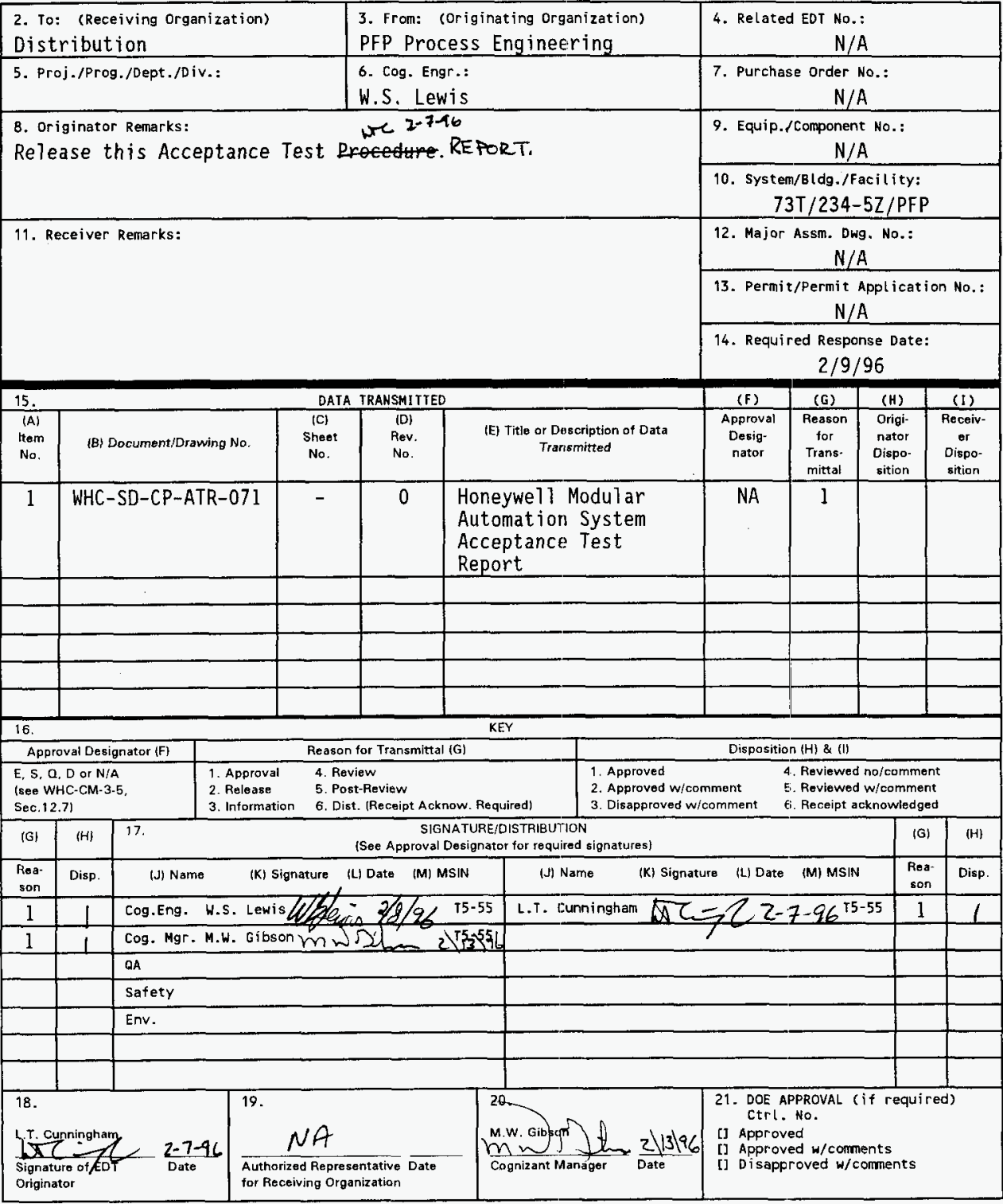




\title{
Honeywell Modular Automation System Acceptance Test Report
}

\author{
L.T. Cunningham \\ Westinghouse Hanford Co., Richland, WA 99352 \\ U.S. Department of Energy Contract DE-AC06-87RL10930 \\ $\begin{array}{lll}\text { EDT/ECN: } & 610798 & \text { UC: UC-506 } \\ \text { Org Code: } & 15530 & \text { Charge Code: } \\ \text { B\&R Code: } & \text { EW7003000 } & \text { Total Pages: } 36\end{array}$
}

Key Words: Honeywe11, Modular Automation System, MAS, Therma1

Stabilization, Acceptance Test Report

Abstract: This document provides the results of the Acceptance Test Procedure for the Honeywell Modular Automation System.

Honeywell is a registered trademark of Honeywell Inc., Minneapolis, MN.

Fluke is a registered trademark of Fluke Corporation, Everett, WA.

Transmation, Minitemp, and Flexitester are registered trademarks of Transmation Inc., Rochester, NY.

TRADEMARK DISCLAIMER. Reference herein to any specific comercial product, process, or service by trade name, trademark, manufacturer, or otherwise, does not necessarily constitute or imoly its endorsenent, recommendation, or favoring by the United States Government or any agency thereof or its contractors or subcontractors.

Printed in the United States of America. To obtain copies of this document, contact: WHC/BCS Document Control Services, P.0. Box 1970, Mailstop H6-08, Richitat Wh 99352; - Phone (509) 372.2420 ; Fax (509) $376-4989$.
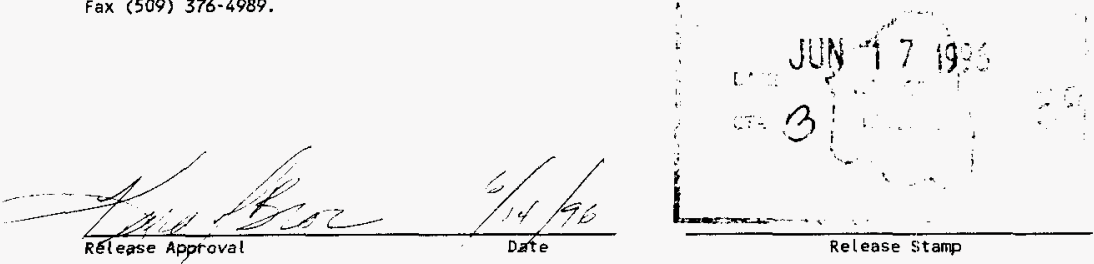


\begin{tabular}{|l|c|l|}
\hline $\begin{array}{l}\text { ACCEPTANCE TEST } \\
\text { REPORT }\end{array}$ & HONEYWELL MODULAR AUTOMATION \\
SYSTEM & $\begin{array}{l}\text { WHC-SD-CP-ATR-071 } \\
\text { REV-0 } \\
\text { PAGE } 2 \text { OF } 36\end{array}$ \\
\hline
\end{tabular}

\subsection{INTRODUCTION}

This test report documents the results from the acceptance testing of the Honeywell Modular Automation System (MAS). The test was performed using WHC-SD-CP-ATP-071, "Honeywell Modular Automation System Acceptance Test Procedure" in conjunction with Job Control System work package 2Z-96-162. A completed copy of the test is attached as Appendix A.

The Honeywell MAS will be installed in Room 230A to control six thermal stabilization furnaces in gloveboxes HA-2OMB and HA-2lI. The use of this system eliminates the need for discrete controllers and alarm switches for each of the furnaces.

\subsection{TEST RESULT DISCUSSION}

The performance of the acceptance test was completed with only one minor exception. During testing, it was observed that the analog inputs were not immediately recognized. In some instances, it required up to 5 minutes for the PLC to accept input from test thermocouples or from the transmation PPS flexitester. Once recognition was achieve, the input could be manipulated without difficulty. Since test was completed, the deviation alarm has been set to $\pm 20^{\circ} \mathrm{C}$ from $\pm 25^{\circ} \mathrm{C}$. The expected change to the deviation alarm has not taken place and this action will bring the programming into line with current documentation.

\section{Exception Resolution}

When performing the thermocouple input checks, it was discerned that the expected display range (input temperature $\pm 0.5^{\circ} \mathrm{C}$ ) was to restrictive for this system. Nine of the 24 analog input addresses had greater than $0.5^{\circ} \mathrm{C}$ display errors. However, the greatest difference in display temperature to input temperature was less than $2^{\circ} \mathrm{C}$ at $1000^{\circ} \mathrm{C}$. This is less than a $0.2 \%$ error of the thermocouple range. A more reasonable error range of $2 \%$ for display readings should have been required. 


\begin{tabular}{|l|c|l|}
\hline $\begin{array}{l}\text { ACCEPTANCE TEST } \\
\text { REPORT }\end{array}$ & HONEYWELL MODULAR AUTOMATION \\
SYSTEM & $\begin{array}{l}\text { WHC-SD-CP-ATR-071 } \\
\text { REV } 0 \\
\text { PAGE 3 OF 36 }\end{array}$ \\
\hline
\end{tabular}

\section{APPENDIX A}




\section{Honeywell Modular Automation System Acceptance Test Procedure}

L.T. Cunningham

Westinghouse Hanford Co., Richland, WA 99352

U.S. Department of Energy Contract DE-ACO6-87RL10930

EDT/ECN: 610800

UC: UC-506

Org Code: 15530

Charge Code: K6134

B\&R Code: EW7003000

Total Pages: 33

Key Words: Honeywe11, Modular Automation System, MAS, Therma? Stabilization, Acceptance Test

Abstract: This document provides instruction for the operational testing of the 6 new stabilization furnaces being installed in HA-20MB and $H A-21 I$ and ancillary equipment.

TRADEMARK DISCLAIMER. Reference herein to any specific comercial product, process, or service by trade name, trademark, manufacturer, or otherwise, does not necessarily constitute or imply its endorsement, recommendation, or favoring by the United States Government or any agency thereof or its contractors or subcontractors.

Printed in the United States of America. To obtain copies of this document, contazt: WHC/BCS Document Control Services, P.0. Box 1970, Mailstop H6-08, Richland WA 99352, Phone (509) 372-2420; Fax $(509) 376-4989$.
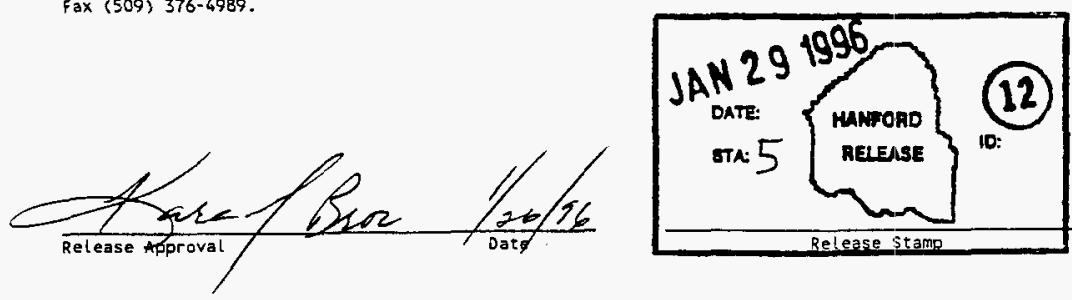

Approved for Public Release 


\begin{tabular}{|l|c|l|}
\hline $\begin{array}{l}\text { ACCEPTANCE TEST } \\
\text { PROCEDURE }\end{array}$ & HONEYWELL MODULAR AUTOMATION \\
SYSTEM & $\begin{array}{l}\text { WHC-SD-CP-ATR-071 } \\
\text { REV-0 LK. } \\
\text { PAGE } 2 \text { - } 33-5 \text { of } 36\end{array}$ \\
\hline
\end{tabular}

TABLE OF CONTENTS

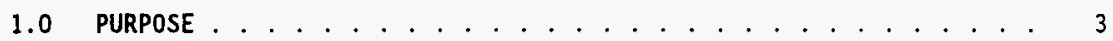

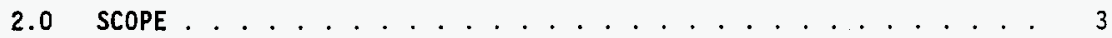

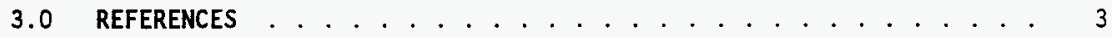

4.0 RESPONSIBILITIES . . . . . . . . . . . . . . . . 3

5.0 SYSTEM DESCRIPTION .......................... 5

6.0 SAFETY .............................. 5

7.0 TEST CONDITIONS AND EQUIPMENT REQUIRED ............ 6

8.0 PROCEDURE . . . . . . . . . . . . . . . . . . . 7

Thermocouple Input Checks . . . . . . . . . . . . . . . . . . 7

Check Analog Output for SCR . . . . . . . . . . . . . . . 9

Interlock validation . . . . . . . . . . . . . . . . . . . 11

Check Digital Signals for Off-Gas Fans ........... 18

9.0 EXCEPTIONS LIST . . . . . . . . . . . . . . . . . . . . . 20

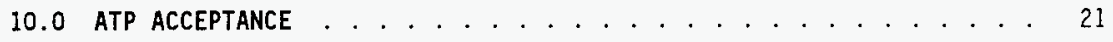

APPENDIX A . . . . . . . . . . . . . . . . . 22

Figure 1 - Honeywe1l Modular Automation System (MAS) . . . . . 23

Figure 2 - Digital Input Test Box ............ 24

Figure 3 - Analog Input Module Connection Schematic........ 25

Figure 4 - Analog Output Module Connection Schematic ...... 26

Figure 5 - Digital Input Module Connection Schematic . . . . . . 27

Figure 6 - Digital Output Module Connection Schematic ...... 28

APPENDIX B . . . . . . . . . . . . . . . . . . . . . . 29

Data Sheet 1 - HA-2OMB Temperature Inputs . . . . . . 30

Data Sheet 2 - HA-21I Temperature Inputs ......... 32 


\begin{tabular}{|l|r|l|}
\hline $\begin{array}{l}\text { ACCEPTANCE TEST } \\
\text { PROCEDURE }\end{array}$ & HONEYWELL MODULAR AUTOMATION \\
SYSTEM & $\begin{array}{l}\text { WHC-SD-CP-ATR-071 } \\
\text { REV-0 LRC } \\
\text { PAGE } 3 \text {-OF } 336 \text { of } 36\end{array}$ \\
\hline
\end{tabular}

\subsection{PURPOSE}

The purpose of this Acceptance Test Procedure (ATP) is to verify the operability of the six new furnaces as controlled by the new Honeywell Modular Automation System (MAS). The Honeywell MAS is being installed in the PFP to control the six thermal stabilization furnaces in gloveboxes HA-20MB and HA-21I.

\subsection{SCOPE}

This ATP provides instructions for testing the configuration of the Honeywell MAS at the Plutonium Finishing Plant (PFP). The test will be a bench test of the analog inputs, analog outputs, and softiware interlocks. The interlock test will check the digital input and outputs. Field equipment will not be connected for this test. Simulated signals will be used for thermocouple and limit sivitch inputs. An Operational Test Procedure (OTP) will be written to perform field testing once the MAS and furnaces have been installed.

\subsection{REFERENCES}

WHC-IP-1026, Engineering Practice Guidelines, Appendix M

\subsection{RESPONSIBILITIES}

\section{Test Director}

The test director will be selected from the PFP Process Engineering Group. The Test Director shall:

- Coordinate and direct acceptance testing.

- Confirm that al1 prestart requirements have been met before allowing the test to begin.

- If needed, alter the test sequence after verifying that there is no adverse impact.

- Ensure that the system is left in a safe mode if the test is to be suspended for a period of time.

- Reverify test prerequisites before restarting a suspended test.

- Initial each step in the test procedure as it is performed.

- Evaluate the need to make changes to the test and initiate ECNs to document those changes.

- Review and approve test data sheets and exceptions.

- Approve resolution to test exceptions. 


\begin{tabular}{|l|c|l|}
\hline $\begin{array}{l}\text { ACCEPTANCE TEST } \\
\text { PROCEDURE }\end{array}$ & $\begin{array}{c}\text { HONEYWELL MODULAR AUTOMATION } \\
\text { SYSTEM }\end{array}$ & $\begin{array}{l}\text { WHC-SD-CP-ATR-071 } \\
\text { REV-0 } \\
\text { PAGE 46E-337 of } 36\end{array}$ \\
\hline
\end{tabular}

\subsection{RESPONSIBILITIES (cont.)}

\section{Witnesses}

A test witness shall be provided by Quality Assurance. Test witnesses shall:
- Witness all or selected portions of the test.
- Review and approve test data sheets and exceptions for the sections of the test that they witness.
- Approve resolution to test exceptions for the sections of the test that they witness.

\section{Test Performer}

The person performing the test shall be designated by the test director. The performer shat1:

- Perform the test under the direction of the test director.

- Record required information on the test data sheets as well as initial and date the form. 


\begin{tabular}{|l|r|l|}
\hline $\begin{array}{l}\text { ACCEPTANCE TEST } \\
\text { PROCEDURE }\end{array}$ & HONEYWELL MODULAR AUTOMATION \\
SYSTEM & $\begin{array}{l}\text { WHC-SO-CP-ATR-071 } \\
\text { REV-0 15e } \\
\text { PAGE } 5-67338 \text { of } 36\end{array}$ \\
\hline
\end{tabular}

\subsection{SYSTEM DESCRIPTION}

The thermal stabilization furnaces will be used to stabilize plutonium bearing materials at the PFP for long term storage. Six new furnaces located in gloveboxes HA-2OMB and HA-21I will be connected to a Honeywell MAS (see Figure 1). The control configuration of the Honeywell MAS provides temperature control to heat the furnaces to $1000^{\circ} \mathrm{C}$ and hold for a prescribed duration depending on the type of material being heated in the furnace. Analog input signals being processed by the MAS include: furnace control temperature, furnace high alarm temperature, furnace off-gas temperature, and glovebox temperature. Analog output signals are sent to the Silicon Control Rectifier (SCR) to supply power to the furnaces. Digital inputs include the furnace door limit switches and a power signal from the off-gas fans. Digital outputs include relay power from the furnace interlock logic and the off-gas fan start/stop signal.

\subsection{SAFETY}

A pre-job safety meeting shall be conducted in accordance with Plutonium Operation Administration Manual, WHC-IP-0821, Chapter 12, Section 5.12 and meeting attendance shall be documented in Table 1 by Process Engineering prior to work start. This ATP shall be read and discussed in detail by alt personnel involved with its performance.

\begin{tabular}{|c|c|c|c|}
\hline \multicolumn{4}{|c|}{$\begin{array}{c}\text { TABLE } 1 \\
\text { PRE-JOB SAFETY/OPERABILITY BRIEFING LIST } \\
\end{array}$} \\
\hline \multicolumn{4}{|c|}{ PRESENTER: $\bar{T} \mathrm{C} \rightarrow \mathrm{C}$} \\
\hline ATTENDEES & ORGANIZATION & ATTENDEES & ORGANIZATION \\
\hline$P_{\text {mece }}$ Alous & pep QC & & \\
\hline We DLL. & 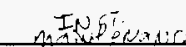 & & \\
\hline 1 & & & \\
\hline & & & \\
\hline & & & \\
\hline & & & \\
\hline & & & \\
\hline & & & \\
\hline
\end{tabular}




\begin{tabular}{|l|c|l|}
\hline $\begin{array}{l}\text { ACCEPTANCE TEST } \\
\text { PROCEDURE }\end{array}$ & $\begin{array}{r}\text { HONEYWELL MODULAR AUTOMATION } \\
\text { SYSTEM }\end{array}$ & $\begin{array}{l}\text { WHC-SD-CP-ATR-071 } \\
\text { REV-0 } \\
\text { PAGE } 6 \text { OFC } 339 \text { of } 36\end{array}$ \\
\hline
\end{tabular}

\subsection{TEST CONDITIONS AND EQUIPMENT REQUIRED}

The control configuration acceptance test will be performed in room 23 of 270-Z in the PFP complex. The personal computer (PC) will be connected to the Honeywell MAS with a coaxial cable. The 50-ohm terminating resistors will be in place.

A special test box will be used to test the function of the $115 \mathrm{~V}$ discreet inputs (see Figure 2). The box contains four separate test points. Each point has its own switch and removable cable. The cable is connected to the address point and the common (Tl, T2, BI, or B2). To turn on the input, the switch is closed, and to turn it off, the switch is opened. To prevent electric shock, any unused electric cables must be disconnected from the box. In addition, the cable niust be disconnected from the box whenever connecting or disconnected from the digital input card.

Current measurement and continuity checks will be taken with a FLUKE 8060A:

Device ID \#273-45-08-003

Last Cal ibrated $9-12-95$
Next Calibration $9-12-96$

For Type $K$ thermocouple signal generation, either of the following instruments can be utilized:

Calibrated Transmation PPS minitemp Calibrator, Model 1064 P

Device ID \#777-13-20-009

Last Ca] ibrated $5-24-95$

$\mathrm{OR}$ Next Calibration $5-24-96$.

Calibrated Transmation PPS Flexitester, Model 1080

Device ID \#

Last Calibrated

Next Calibration 


\begin{tabular}{|l|c|l|}
\hline $\begin{array}{l}\text { ACCEPTANCE TEST } \\
\text { PROCEDURE }\end{array}$ & HONEYWELL MODULAR AUTOMATION \\
SYSTEM & $\begin{array}{l}\text { WHC-SD-CP-ATR-071 } \\
\text { REV-0 } \\
\text { PAGE }\end{array}$ \\
\hline
\end{tabular}

\subsection{PROCEDURE}

Discrepancies will be noted on the Exceptions List provided (Section 8.0) and according to provisions outl ined in WHC-IP-1026, Engineering Practice Guidelines, Appendix M.

LT 8.1 Download the current controller configuration to the logic controller.

$\lfloor\pi$ 8.2 Enter VIEW from the windows screen and acknowledge all alarms.

Thermocouple Input Checks (see Figure 3)

WTC 8.3 From the FURNACE 20MB-1 screen, test the following temperature inputs for FUR-2OMB-1.

$x^{y}$

8.3.1 Input compensated temperature inputs to Address 0 per data sheet 1 to check temperature controller thermocouple input.

0

8.3.2 Input compensated temperature inputs to Address 1 per data sheet I to check furnace high temperature alarm thermocouple input.

WC 8.3 .3 Input compensated temperature inputs to Address 9 per data sheet 1 to check off-gas thermocouple input.

UK 8.4 From the FURNACE 2OMB-2 screen, test the following temperature inputs for FUR-2OMB-2.

1K2 8.4.1 Input compensated temperature inputs to Address 2 per data sheet 1 to check temperature controller thermocouple input.

I 8.4 .2 Input compensated temperature inputs to Address 3 per data sheet 1 to check furnace high temperature alarm thermocouple input.

WN 8.4.3 Input compensated temperature inputs to Address 10 per data sheet 1 to check off-gas thermocouple input.

WC 8.5 From the FURNACE 2OMB-3 screen, test the following temperature inputs for FUR-20MB-3.

Wh 8.5.1 Input compensated temperature inputs to Address 4 per data sheet 1 to check temperature controller thermocouple input.

WC 8.5.2 Input compensated temperature inputs to Address 5 per data sheet 1 to check furnace high temperature alarm thermocouple input. 


\begin{tabular}{|l|c|l|}
\hline $\begin{array}{l}\text { ACCEPTANCE TEST } \\
\text { PROCEDURE }\end{array}$ & HONEYWELL MODULAR AUTOMATION \\
SYSTEM & $\begin{array}{l}\text { WHC-SD-CP-ATR-071 } \\
\text { REV-0 tKC } \\
\text { PAGE \& } 3311 \text { of } 36\end{array}$ \\
\hline
\end{tabular}

\subsection{PROCEDURE (cont.)}

L2 8.5.3 Input compensated temperature inputs to Address 11 per data sheet 1 to check off-gas thermocouple input.

Lte 8.6 From the FURNACE OVERVIEW screen, test the following temperature inputs for glovebox HA-20MB.

LC 8.6.1 Connect blank test thermocouples to Addresses 7 and 8 . Input compensated temperature inputs to Address 6 per data sheet 1 to glovebox thermocouple input.

W. 8.6 .2 Connect blank test thermocouples to Addresses 6 and 8 . Input compensated temperature inputs to Address 7 per data sheet 1 to glovebox thermocouple input.

UT 8.6.3 Connect blank test thermocouples to Addresses $E$ and 7 . Input compensated temperature inputs to Address 8 per data sheet 1 to glovebox thermocouple input.

W 8.7 From the FURNACE 21 I-1 screen, test the following temperature inputs for FUR-21I-1.

Wt 8.7 .1 Input compensated temperature inputs to Address 32 per data sheet 2 to check temperature controller thermocouple input.

WT 8.7 .2 Input compensated temperature inputs to Address 33 per data sheet 2 to check furnace high temperature alarm thermocouple input.

LC.

8.7.3 Input compensated temperature inputs to Address 41 per data sheet 2 to check off-gas thermocouple input.

DT 8.8 From the FURNACE 2II-2 screen, test the following temperature inputs for FUR-2lI-2.

IX 8.8.1 Input compensated temperature inputs to Address 34 per data sheet 2 to check temperature controller thermocouple input.

WT 8.8.2 Input compensated temperature inputs to Address 35 per data sheet 2 to check furnace high temperature alarm thermocouple input.

$1 \pi$ 8.8.3 Input compensated temperature inputs to Address 42 per data sheet 2 to check off-gas thermocouple input. 


\begin{tabular}{|l|c|l|}
\hline \hline $\begin{array}{l}\text { ACCEPTANCE TEST } \\
\text { PROCEDURE }\end{array}$ & $\begin{array}{l}\text { HONEYWELL MODULAR AUTOMATION } \\
\text { SYSTEM }\end{array}$ & $\begin{array}{l}\text { WHC-SD-CP-ATR-071 } \\
\text { REV-0 } \\
\text { PAGE } 9 \text { ST } 33 \text { 12 of } 36\end{array}$ \\
\hline
\end{tabular}

\subsection{PROCEDURE (cont.)}

WT 8.9 From the FURNACE 21 I-3 screen, test the following temperature inputs for FUR-211-3.

W 8.9.1 Input compensated temperature inputs to Address 36 per data sheet 2 to check temperature controller thermocouple input.

L 8.9 .2 Input compensated temperature inputs to Address 37 per data sheet 2 to check furnace high temperature alarm thermocouple input.

LTC 8.9.3 Input compensated temperature inputs to Address 43 per ata sheet 2 to check off-gas thermocouple input.

ITC 8.10 From the FURNACE OVERVIEW screen, test the following temperature inputs for glovebox HA-21I.

ITC 8.10.1 Connect b]ank test thermocoup Tes to Addresses 39 and 40. Input compensated temperature inputs to Address 38 per data sheet 2 to glovebox thermocouple input.

We 8.10.2 Connect blank test thermocouples to Addresses 38 and 40. Input compensated temperature inputs to Address 39 per data sheet 2 to glovebox thermocouple input.

10 8.10.3 Connect blank test thermocouples to Addresses 38 and 39. Input compensated temperature inputs to Address 40 per data sheet 2 to glovebox thermocouple input.

Check Analog Output for SCR (see Figure 4)

LXC 8.11 Record the output of address 64 when Output for furnace 20MB-1 is $0 \%$ as seen on the FURNACE $20 \mathrm{MB}-1$ screen. $3.95 \mathrm{~mA}$

$1 \pi$ 8.12 From FURNACE 2OMB-1 screen, start heating cycle by pressing the 1-OXIDE button.

LKC 8.13 Monitor output of address 64 . Output sha11 be in $4-20 \mathrm{~mA} \pm 0.1 \mathrm{~mA}$ range and should increase as the setpoint climbs.

L 8.14 Record output for address 64 when Output for furnace 20MB-1 is $100 \%$ as seen on the FURNACE $20 \mathrm{MB}-1$ screen. $19.95 \mathrm{~mA}$

WTC 8.15 Stop heating cycle by pressing Stop Cycle button.

WK 8.16 Record the output of address 65 when Output for furnace 20MB-2 is $0 \%$ as seen on the FURNACE 20MB-2 screen. $3.95 \mathrm{~mA}$ 


\begin{tabular}{|l|l|l|}
\hline $\begin{array}{l}\text { ACCEPTANCE TEST } \\
\text { PROCEDURE }\end{array}$ & $\begin{array}{r}\text { HONEYWELL MODULAR AUTOMATION } \\
\text { SYSTEM }\end{array}$ & $\begin{array}{l}\text { WHC-SD-CP-ATR-071 } \\
\text { REV-0 } \\
\text { PAGE }\end{array}$ \\
\hline
\end{tabular}

\subsection{PROCEDURE (cont.)}

WTC 8.17 From FURNACE 2OMB-2 screen, start heating cycle by pressing the 1-OXIDE button.

WC 8.18 Monitor output of address 65 . Output sha77 be in $4-20 \mathrm{~mA} \pm 0.1 \mathrm{~mA}$ range and should increase as the setpoint climbs.

17. 8.19 Record output for address 65 when Output for furnace 20MB-2 is $100 \%$ as seen on the FURNACE $20 \mathrm{MB}-2$ screen. $19.95 \mathrm{~mA}$

LKC 8.20 Stop heating cycle by pressing Stop Cycle button.

We 8.21 Record the output of address 66 when output for furnace 20MB-3 is $0 \%$ as seen on the FURNACE 2OMB-3 screen. $3.96 \mathrm{~mA}$

WT 8.22 From FURNACE 20MB-3 screen, start heating cycle by pressing the 1-OXIDE button.

WT 8.23 Monitor output of address 66 . Output shal1 be in $4-20 \mathrm{~mA} \pm 0.1 \mathrm{~mA}$ range and should increase as the setpoint climbs.

LIC 8.24 Record output for address 66 when Output for furnace 20MB-3 is $100 \%$ as seen on the FURNACE $20 \mathrm{MB}-3$ screen. $19.95 \mathrm{~mA}$

ITC 8.25 Stop heating cycle by pressing Stop Cycle button.

UTC 8.26 Record the output of address 72 when Output for furnace 21I-1 is $0 \%$ as seen on the FURNACE $21 \mathrm{I}-1$ screen. $3.96 \mathrm{~mA}$.

WTC 8.27 From FURNACE $211-1$ screen, start heating cycle by pressing the 1-0XIDE button.

Le 8.28 Monitor output of address 72. Output sha7l be in $4-20 \mathrm{~mA} \pm 0.1 \mathrm{~mA}$ range and should increase as the setpoint climbs.

We 8.29 Record output for address 72 when Output for furnace $21 \mathrm{I}-1$ is $100 \%$ as seen on the FURNACE $21 \mathrm{I}-1$ screen. $19.94 \mathrm{~mA}$

UK 8.30 Stop heating cycle by pressing Stop Cycle button.

WT 8.31 Record the output of address 73 when Output for furnace $21 \mathrm{I}-2$ is $0 \%$ as seen on the FURNACE $21 \mathrm{I}-2$ screen. 3,94 mA

WTC 8.32 From FURNACE 21 I-2 screen, start heating cycle by pressing the 1-OXIDE button.

WTC 8.33 Monitor output of address 73 . Output shall be in $4-20 \mathrm{~mA} \pm 0.1 \mathrm{~mA}$ range and should increase as the setpoint climbs. 


\begin{tabular}{|l|c|l|}
\hline $\begin{array}{l}\text { ACCEPTANCE TEST } \\
\text { PROCEDURE }\end{array}$ & $\begin{array}{l}\text { HONEYWELL MODULAR AUTOMATION } \\
\text { SYSTEM }\end{array}$ & $\begin{array}{l}\text { WHC-SD-CP-ATR-071 } \\
\text { REV-0 LR. } \\
\text { PAGE }+1-3314 \text { of } 36\end{array}$ \\
\hline
\end{tabular}

\subsection{PROCEDURE (cont.)}

LC 8.34 Record output for address 73 when output for furnace 21 I-2 is $100 \%$ as seen on the FURNACE $21 \mathrm{I}-2$ screen. $19.95 \mathrm{~mA}$

LT 8.35 Stop heating cycle by pressing Stop Cycle button.

We 8.36 Record the output of address 74 when Output for furnace 211-3 is $0 \%$ as seen on the FURNACE $21 \mathrm{I}-3$ screen. $3.95 \mathrm{~mA}$

we 8.37 From FURNACE $211-3$ screen, start heating cycle by pressing the 1-0XIDE button.

Le 8.38 Monitor output of address 74 . Output shall be in $4-20 \mathrm{~mA} \pm 0.1 \mathrm{~mA}$ range and should increase as the setpoint climbs.

LTC 8.39 Record output for address 74 when Output for furnace $211-3$ is $100 \%$ as seen on the FURNACE $21 \mathrm{I}-3$ screen. $19.94 \mathrm{~mA}$

WC 8.40 Stop heating cycle by pressing Stop Cycle button.

Interlock Validation

WT 8.41 On the Digital Input card 621-1100R, ensure the jumpers are connected across contact points $\mathrm{B} 1$ and $\mathrm{B} 2$ and contact points $\mathrm{T} 1$ and $\mathrm{T} 2$. (see Figure 5 )

WT 8.42 On the Digital Output card 621-2100R, ensure the jumpers are connected across contact points BI and B2 and contact points $\mathrm{T} 1$ and T2. (see Figure 6)

He 8.43 Insta11 test thermocouples to addresses $0-11$ and $32-43$ on the UAIs.

WR 8.44 On the FURNACE OVERVIEW Screen, ensure EMERGENCY SHUTDOWN button is RED. Push EMERGENCY SHUTDOWN button if gray.

We 8.45 Connect Digital input test box to input addresses $80,81,82$, and 83. The common $(-)$ is to be connected to BI/B2.

We 8.46 Close contacts $80,81,82$, and 83 . The furnace doors should be closed on FURNACE OVERVIEW screen for FUR-2OMB-1, FUR-2OMB-2, FUR-2OMB-3, and FUR-2II-1.

8.47 Perform Furnace FUR-20MB-1 interlock validation.

8.47.1 From FURNACE 2OMB-1 screen, start heating cycle by pressing the 1-OXIDE button.

We 8.47.2 Verify continuity for address 88 on the DI card. 


\begin{tabular}{|l|r|l|}
\hline $\begin{array}{l}\text { ACCEPTANCE TEST } \\
\text { PROCEDURE }\end{array}$ & HONEYWELL MODULAR AUTOMATION \\
SYSTEM & $\begin{array}{l}\text { WHC-SD-CP-ATR-071 } \\
\text { REV-0 } \\
\text { PAGE }\end{array}$ & \\
\hline
\end{tabular}

\subsection{PROCEDURE (cont.)}

\begin{tabular}{|c|c|c|}
\hline 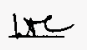 & 8.47 .3 & Open contact 80 with DI test box. \\
\hline $1 \pi$ & 8.47 .4 & Verify open circuit for address 88 . \\
\hline Drc & 8.47 .5 & Verify door to furnace FUR-2OMB-1 opens. \\
\hline wat & 8.47 .6 & Close contact 80 with DI test box. \\
\hline W & 8.47 .7 & Verify continuity for address 88 \\
\hline Wre & 8.47 .8 & Verify door to furnace FUR-20MB-1 closes. \\
\hline$\omega$ & 8.47 .9 & Press Stop Cycle Button. \\
\hline We & 8.47 .10 & Verify open circuit for address 88 . \\
\hline$w \pi$ & 8.47 .11 & Restart heating cycle by pressing the 1-0XIDE button. \\
\hline we & 8.47 .12 & Verify closed circuit for address 88 \\
\hline we & 8.47 .13 & $\begin{array}{l}\text { Wait for deviation alarm to annunciated when setpoint } \\
\text { is } 25 \pm 1^{\circ} \mathrm{C} \text { above furnace temperature. }\end{array}$ \\
\hline wr. & 8.47 .14 & Verify open circuit for address 88 \\
\hline WTC & 8.47 .15 & $\begin{array}{l}\text { Remove test thermocouple from address } 1 \text { and input } \\
\text { compensated temperature of } 1055^{\circ} \mathrm{C} \text {. }\end{array}$ \\
\hline $10 \pi$ & 8.47 .16 & $\begin{array}{l}\text { Restart heating cycle by pressing the Stop cycle } \\
\text { button and then the I-OXIDE button. }\end{array}$ \\
\hline Wre & 8.47 .17 & Verify open circuit for address 88. \\
\hline Mr. & 8.47 .18 & Replace test thermocouple in address 1 . \\
\hline WR & 8.47 .19 & Verify closed circuit for address 88. \\
\hline Ine & 8.47 .20 & $\begin{array}{l}\text { Remove test thermocouple from address } 6 \text { ard input } \\
\text { compensated temperature of } 75^{\circ} \mathrm{C} \text {. }\end{array}$ \\
\hline b. & 8.47 .21 & Verify open circuit for address 88 \\
\hline $\ln$ & 8.47 .22 & Replace test thermocouple in address 6 . \\
\hline Wr. & 8.47 .23 & Verify closed circuit for address 88. \\
\hline $1 \pi$ & 8.47 .24 & Press Emergency Stop Button. \\
\hline
\end{tabular}




\begin{tabular}{|l|r|l|}
\hline $\begin{array}{l}\text { ACCEPTANCE TEST } \\
\text { PROCEDURE }\end{array}$ & $\begin{array}{r}\text { HONEYWELL MODULAR AUTOMATION } \\
\text { SYSTEM }\end{array}$ & $\begin{array}{l}\text { WHC-SD-CP-ATR-071 } \\
\text { REV-0 LR } \\
\text { PAGE 13-OF 33 16 of 36 }\end{array}$ \\
\hline
\end{tabular}

\subsection{PROCEDURE (cont.)}

Wx 8.47.25 Verify open circuit for address 88.

8.48 Perform Furnace FUR-20MB-2 interlock validation.

We 8.48.1 From FURNACE 2OMB-2 screen, start heating cycle by pressing the 1-OXIDE button.

WT2 8.48.2 Verify continuity for address 89 on the DI card.

Wr 8.48.3 Open contact 81 with DI test box.

Wr 8.48.4 Verify open circuit for address 89.

We 8.48 .5 Verify door to furnace FUR-20MB-2 opens.

W $8.48 .6 \quad$ Close contact 81 with DI test box.

WT 8.48.7 Verify continuity for address 89 .

W 8.48.8 Verify door to furnace FUR-20MB-2 closes.

W 8.48 .9 Press Stop Cycle Button.

Whe 8.48 .10 Verify open circuit for address 89.

WT 8.48.11 Restart heating cycle by pressing the 1-OXIDE button.

Whe 8.48.12 Verify closed circuit for address 89.

Wh 8.48.13 Wait for deviation alarm to annunciated when setpoint is $25 \pm 1^{\circ} \mathrm{C}$ above furnace temperature.

4] 8.48.14 Verify open circuit for address 89.

we 8.48.15 Remove test thermocouple from address 3 and input compensated temperature of $1055^{\circ} \mathrm{C}$.

LCh 8.48 .16 Restart heating cycle by pressing the stop cycle button and then the 1-OXIDE button.

we 8.48 .17 Verify open circuit for address 89

LW 8.48.18 Replace test thermocouple in address 3.

be 8.48 .19 Verify closed circuit for address 89.

Le 8.48.20 Remove test thermocouple from address 7 and input compensated temperature of $75^{\circ} \mathrm{C}$. 


\begin{tabular}{|l|c|l|}
\hline $\begin{array}{l}\text { ACCEPTANCE TEST } \\
\text { PROCEDURE }\end{array}$ & HONEYWELL MODULAR AUTOMATION \\
SYSTEM & $\begin{array}{l}\text { WHC-SD-CP-ATR-07I } \\
\text { REV-0 15C } \\
\text { PAGE 14 OF-33 17 OF 36 }\end{array}$ \\
\hline
\end{tabular}

8.0 PROCEDURE (cont.)

$\begin{array}{lll}\text { wK } & 8.48 .21 & \text { Verify open circuit for address } 89 . \\ \text { we } & 8.48 .22 & \text { Replace test thermocouple in address } 7 . \\ \text { twe } & 8.48 .23 & \text { Verify closed circuit for address } 89 . \\ \text { wK } & 8.48 .24 & \text { Press Emergency Stop Button. } \\ \text { wK } & 8.48 .25 & \text { Verify open circuit for address } 89 .\end{array}$

8.49 Perform Furnace FUR-2OMB-3 interlock validation.

He 8.49.1 From FURNACE 2OMB-3 screen, start heating cycle by pressing the 1-OXIDE button.

Le 8.49 .2 Verify continuity for address 90 on the DI card.

Wh 8.49 .3 Open contact 82 with DI test box.

Le 8.49 .4 Verify open circuit for address 90.

Wh 8.49 .5 Verify door to furnace FUR-20MB-3 opens.

wr 8.49.6 Close contact 82 with DI test box.

we 8.49 .7 Verify continuity for address 90.

we 8.49.8 Verify door to furnace FUR-20MB-3 closes.

Le 8.49.9 Press Stop Cycle Button.

WTe 8.49.10 Verify open circuit for address 90 .

we 8.49.11 Restart heating cycle by pressing the l-OXIDE button.

We 8.49.12 Verify closed circuit for address 90.

We 8.49.13 Wait for deviation alarm to annunciated when setpoint is $25 \pm 1^{\circ} \mathrm{C}$ above furnace temperature.

We 8.49.14 Verify open circuit for address 90.

wh 8.49.15 Remove test thermocouple from address 5 and input compensated temperature of $1055^{\circ} \mathrm{C}$.

WT 8.49.16 Restart heating cycle by pressing the Stop Cycle button and then the 1-OXIDE button. 


\begin{tabular}{|l|c|l|}
\hline $\begin{array}{l}\text { ACCEPTANCE TEST } \\
\text { PROCEDURE }\end{array}$ & $\begin{array}{r}\text { HONEYWELL MODULAR AUTOMATION } \\
\text { SYSTEM }\end{array}$ & $\begin{array}{l}\text { WHC-SD-CP-ATR-071 } \\
\text { REV-0 } \\
\text { PAGE } 15 \text { OF } 3318 \text { of } 36\end{array}$ \\
\hline
\end{tabular}

8.0 PROCEDURE (cont.)

\begin{tabular}{|c|c|c|c|}
\hline $1 \pi$ & & 8.49 .17 & Verify open circuit for address 90. \\
\hline WKC & & 8.49 .18 & Replace test thermocouple in address 5 . \\
\hline$u$ & & 8.49 .19 & Verify closed circuit for address 90. \\
\hline wh & & 8.49 .20 & $\begin{array}{l}\text { Remove test thermocouple from address } 8 \text { and input } \\
\text { compensated temperature of } 75^{\circ} \mathrm{C} \text {. }\end{array}$ \\
\hline $1 \pi$ & & 8.49 .21 & Verify open circuit for address 90. \\
\hline we & & 8.49 .22 & Replace test thermocouple in address 9. \\
\hline $1 \pi$ & & 8.49 .23 & Verify closed circuit for address 90. \\
\hline wer & & 8.49 .24 & Press Emergency Stop Button. \\
\hline we & & 8.49 .25 & Verify open circuit for address 90. \\
\hline & 8.50 & Perform & Furnace FUR-21I-1 interlock validation. \\
\hline Ler & & 8.50 .1 & $\begin{array}{l}\text { From FURNACE } 21 I-1 \text { screen, start heating cycle by } \\
\text { pressing the 1-OXIDE button. }\end{array}$ \\
\hline LTC & & 8.50 .2 & Verify continuity for address 91 on the DI card. \\
\hline we & & 8.50 .3 & Open contact 83 with DI test box. \\
\hline$w \times$ & & 8.50 .4 & Verify open circuit for address 91 . \\
\hline bre & & 8.50 .5 & Verify door to furnace FUR-21I-1 opens. \\
\hline$w \nabla$ & & 8.50 .6 & Close contact 83 with DI test box. \\
\hline w & & 8.50 .7 & Verify continuity for address 91 . \\
\hline 42 & & 8.50 .8 & Verify door to furnace FUR-21I-1 closes. \\
\hline Le & & 8.50 .9 & Press Stop Cycle Button. \\
\hline Ax & & 8.50 .10 & Verify open circuit for address 91 \\
\hline we & & 8.50 .11 & Restart heating cycle by pressing the 1-OXIDE button. \\
\hline$\underline{2 C}$ & & 8.50 .12 & Verify closed circuit for address 91 \\
\hline Wr & & 8.50 .13 & $\begin{array}{l}\text { Wait for deviation alarm to annunciated when setpoint } \\
\text { is } 25 \pm 1^{\circ} \mathrm{C} \text { above furnace temperature. }\end{array}$ \\
\hline
\end{tabular}




\begin{tabular}{|l|c|l|}
\hline $\begin{array}{l}\text { ACCEPTANCE TEST } \\
\text { PROCEDURE }\end{array}$ & $\begin{array}{r}\text { HONEYWELL MODULAR AUTOMATION } \\
\text { SYSTEM }\end{array}$ & $\begin{array}{l}\text { WHC-SD-CP-ATR-071 } \\
\text { REV-0 } \\
\text { PAGE W6 } 33 \text { 19 OF 36 }\end{array}$ \\
\hline
\end{tabular}

\subsection{PROCEDURE (cont.)}

We 8.50.14 Verify open circuit for address 91.

LC.50.15 Remove test thermocouple from address 33 and input compensated temperature of $1055^{\circ} \mathrm{C}$.

ue 8.50.16 Restart heating cycle by pressing the Stop Cycle button and then the 1-OXIDE button.

Le 8.50.17 Verify open circuit for address 91.

be 8.50.18 Replace test thermocouple in address 33.

LC. 8.50.19 Verify closed circuit for address 91.

tec 8.50.20 Remove test thermocouple from address 38 and input compensated temperature of $75^{\circ} \mathrm{C}$.

Lie 8.50.21 Verify open circuit for address 91.

LC 8.50.22 Replace test thermocouple in address 38.

the $\quad 8.50 .23$ Verify closed circuit for address 91 .

Le 8.50.24 Press Emergency Stop Button.

we 8.50 .25 Verify open circuit for address 91.

Le 8.51 Disconnect test box from addresses $80,81,82$, and 83 .

WK 8.52 Connect Digital input test box to input addresses 84 and 85 .

8.53 Perform Furnace FUR-21I-2 interlock validation.

WT 8.53.1 From FURNACE 21I-2 screen, start heating cycle by pressing the 1-OXIDE button.

Wh 8.53.2 Verify continuity for address 92 on the DI card.

IT 8.53.3 Open contact 84 with DI test box.

Wh 8.53 .4 Verify open circuit for address 92.

Le 8.53.5 Verify door to furnace FUR-21I-2 opens.

Lr 8.53.6 Close contact 84 with DI test box.

Le 8.53 .7 Verify continuity for address 92. 


\begin{tabular}{|l|c|l|}
\hline $\begin{array}{l}\text { ACCEPTANCE TEST } \\
\text { PROCEDURE }\end{array}$ & $\begin{array}{c}\text { HONEYWELL MODULAR AUTOMATION } \\
\text { SYSTEM }\end{array}$ & $\begin{array}{l}\text { WHC-SD-CP-ATR-071 } \\
\text { REV-0 WR } \\
\text { PAGE } 17 \text { OF } 3320 \text { of } 36\end{array}$ \\
\hline
\end{tabular}

\subsection{PROCEDURE (cont.)}

Whe 8.53.8 Verify door to furnace FUR-21I-2 closes.

We 8.53 .9 Press Stop Cycle Button.

Let 8.53.10 Verify open circuit for address 92.

Lic 8.53.11 Restart heating cycle by pressing the 1-OKIDE button.

LTC 8.53.12 Verify closed circuit for address 92.

LK 8.53.13 Wait for deviation alarm to annunciated when setpoint is $25 \pm 11^{\circ} \mathrm{C}$ above furnace temperature.

8.53.14 Verify open circuit for address 92.

8.53.15 Remove test thermocouple from address 35 and input compensated temperature of $1055^{\circ} \mathrm{C}$.

LT 8.53.16 Restart heating cycle by pressing the Stop Cycle button and then the 1-OXIDE button.

LT2 8.53.17 Verify open circuit for address 92.

iT 8.53.18 Replace test thermocouple in address 35.

LTC 8.53.19 Verify closed circuit for address 92.

IIC 8.53.20 $\begin{aligned} & \text { Remove test thermocouple from address } 39 \text { and input } \\ & \text { compensated temperature of } 75^{\circ} \mathrm{C} \text {. }\end{aligned}$

WT 8.53.21 Verify open circuit for address 92.

UT 8.53.22 Replace test thermocouple in address 39.

WC 8.53.23 Verify closed circuit for address 92.

匹 8.53.24 Press Emergency Stop Button.

LIC 8.53.25 Verify open circuit for address 92.

8.54 Perform Furnace FUR-21I-3 interlock validation.

Ge 8.54.1 From FURNACE 21I-3 screen, start heating cycle by pressing the 1-OXIDE button.

Le 8.54 .2 Verify continuity for address 93 on the DI card.

be 8.54.3 Open contact 85 with DI test box. 


\begin{tabular}{|l|c|l|}
\hline $\begin{array}{l}\text { ACCEPTANCE TEST } \\
\text { PROCEDURE }\end{array}$ & $\begin{array}{c}\text { HONEYWELL MODULAR AUTOMATION } \\
\text { SYSTEM }\end{array}$ & $\begin{array}{l}\text { WHC-SD-CP-ATR-071 } \\
\text { REV-0 LTC } \\
\text { PAGE }\end{array}$ \\
\hline
\end{tabular}

8.0 PROCEDURE (cont.)

\begin{tabular}{|c|c|c|}
\hline se & 8.54 .4 & Verify open circuit for address 93. \\
\hline 胥 & 8.54 .5 & Verify door to furnace FUR-21I-3 opens. \\
\hline $\bar{z}$ & 8.54 .6 & Close contact 85 with DI test box. \\
\hline 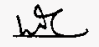 & 8.54 .7 & Verify continuity for address 93. \\
\hline$\tau$ & 8.54 .8 & Verify door to furnace FUR-21I-3 closes. \\
\hline$\underline{v}$ & 8.54 .9 & Press Stop Cycle Button. \\
\hline & 8.54 .10 & Verify open circuit for address 93. \\
\hline & 8.54 .11 & Restart heating cycle by pressing the 1-OXIDE button. \\
\hline & 8.54 .12 & Verify closed circuit for address 93 . \\
\hline$c$ & 8.54 .13 & $\begin{array}{l}\text { Wait for deviation alarm to annunciated when setpoint } \\
\text { is } 25 \pm 1^{\circ} \mathrm{C} \text { above furnace temperature. }\end{array}$ \\
\hline 乙 & 8.54 .14 & Verify open circuit for address 93. \\
\hline & 8.54 .15 & $\begin{array}{l}\text { Remove test thermocouple from address } 37 \text { and input } \\
\text { compensated temperature of } 1055^{\circ} \mathrm{C} \text {. }\end{array}$ \\
\hline & 8.54 .16 & $\begin{array}{l}\text { Restart heating cycle by pressing the Stop cycle } \\
\text { button and then the I-OXIDE button. }\end{array}$ \\
\hline & 8.54 .17 & Verify open circuit for address 93. \\
\hline & 8.54 .18 & Replace test thermocouple in address 37 . \\
\hline D & 8.54 .19 & Verify closed circuit for address 93. \\
\hline & 8.54 .20 & $\begin{array}{l}\text { Remove test thermocouple from address } 40 \text { and input } \\
\text { compensated temperature of } 75^{\circ} \mathrm{C} \text {. }\end{array}$ \\
\hline & 8.54 .21 & Verify open circuit for address 93. \\
\hline & 8.54 .22 & Replace test thermocouple in address 40 . \\
\hline & 8.54 .23 & Verify closed circuit for address 93 . \\
\hline & 8.54 .24 & Press Emergency Stop Button. \\
\hline & 8.54 .25 & Verify open circuit for address 93 . \\
\hline
\end{tabular}




\begin{tabular}{|l|r|l|}
\hline $\begin{array}{l}\text { ACCEPTANCE TEST } \\
\text { PROCEDURE }\end{array}$ & $\begin{array}{r}\text { HONEYWELL MODULAR AUTOMATION } \\
\text { SYSTEM }\end{array}$ & $\begin{array}{l}\text { WHC-SD-CP-ATR-071 } \\
\text { REV-0 } \\
\text { PAGE } 19 \text { UT } 3322 \text { OF 36 }\end{array}$ \\
\hline
\end{tabular}

\subsection{PROCEDURE (cont.)}

WK 8.55 Disconnect test box from addresses 84 , and 85 . Disconnect common from $\mathrm{Bl} / \mathrm{B} 2$.

\section{Check Digital Signals for Off-Gas Fans}

UTC 8.56 On the Digital Output card 621-2100R, ensure the jumpers are connected across contact points $\mathrm{Bl}$ and $\mathrm{B} 2$ and contact points Tl and T2. (see Figure 6)

LIC 8.57 From the OFF-GAS FAN screen, press Vacuum Fan 1 button to close contact. Motor and part of line going through the motor should turn RED.

LIC 8.58 Verify continuity between contact 7 (address 94 ) and B1/B2 on the digital input card.

IC 8.59 From the OFF-GAS FAN screen, press Vacuum Fan I button to open contact. Motor and part of line going through the motor should turn black.

LK 8.60 Verify open circuit between contact 7 (address 94) and $\mathrm{B1} / \mathrm{B2}$ on the digital input card.

LK 8.61 From the OFF-GAS FAN screen, press Vacuum Fan 2 button to close contact. Motor and part of line going through the motor should turn RED.

LC 8.62 Verify continuity between contact 8 (address 95 ) and $\mathrm{B} 1 / \mathrm{B} 2$ on the digital input card.

LIC 8.63 From the OFF-GAS FAN screen, press Vacuum Fan 2 button to open contact. Motor and part of line going through the motor should turn black.

WC 8.64 Verify open circuit between contact 8 (address 95) and BI/B2 on the digital input card.

L区 8.65 Connect Digital input test box to input address 86 . The common $(-)$ is to be connected to $\mathrm{Bl} / \mathrm{B} 2$.

WC 8.66 Close circuit to address 86 and verify that the OFF-GAS FAN 1 ight changes to red.

Le 8.67 Open circuit to address 86 and verify that the OFF-GAS FAN light changes to white.

LC 8.68 Disconnect test box from address 86 . Disconnect common from $\mathrm{B} 1 / \mathrm{B2}$. 


\begin{tabular}{|l|r|l|}
\hline $\begin{array}{l}\text { ACCEPTANCE TEST } \\
\text { PROCEDURE }\end{array}$ & HONEYWELL MODULAR AUTOMATION \\
SYSTEM & $\begin{array}{l}\text { WHC-SD-CP-ATR-071 } \\
\text { REV-0 } \\
\text { PAGE 20 20 }\end{array}$ & 230 OF 36 \\
\hline
\end{tabular}

\subsection{EXCEPTIONS LIST}

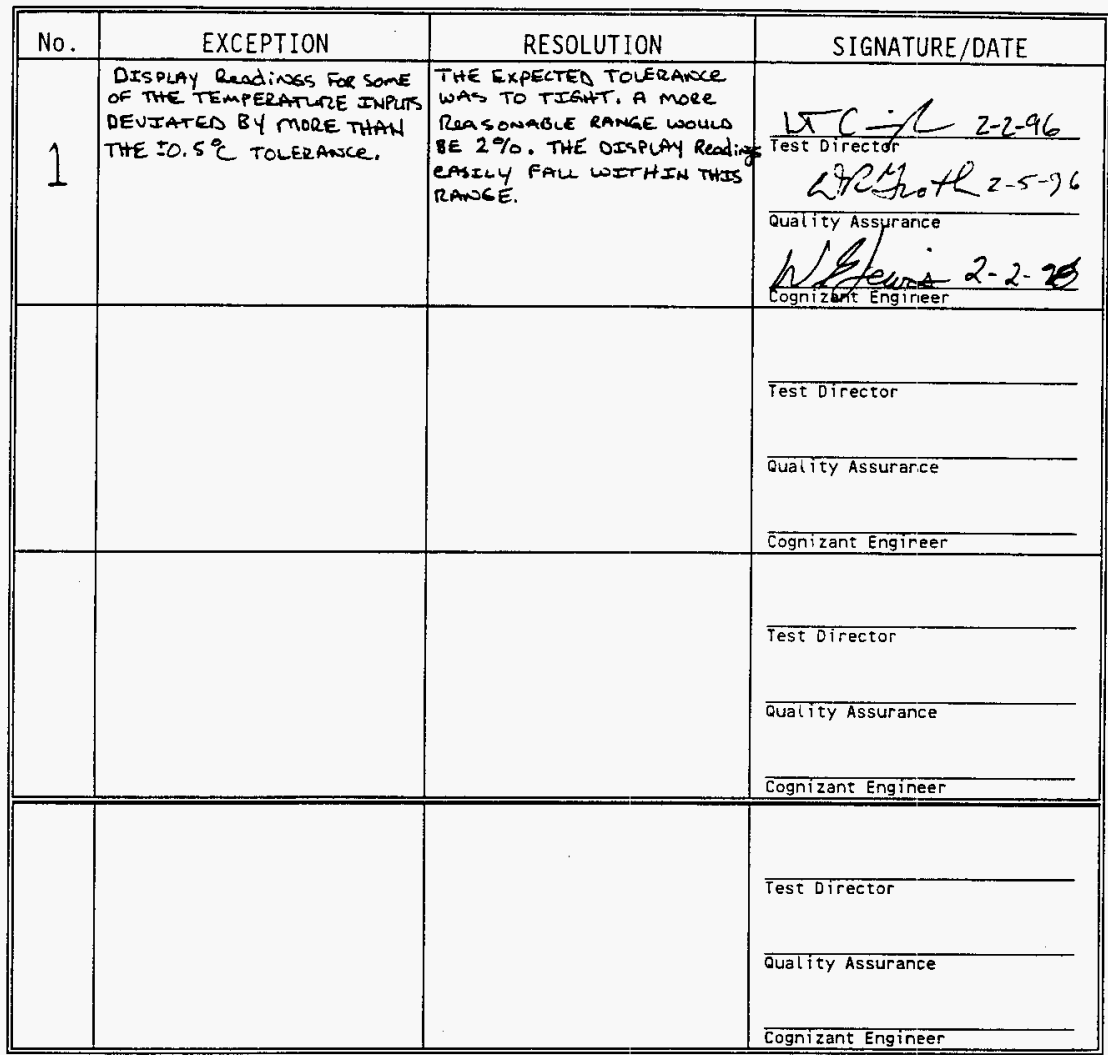




\begin{tabular}{|l|c|l|}
\hline $\begin{array}{l}\text { ACCEPTANCE TEST } \\
\text { PROCEDURE }\end{array}$ & $\begin{array}{l}\text { HONEYWELL MODULAR AUTOMATION } \\
\text { SYSTEM }\end{array}$ & $\begin{array}{l}\text { WHC-SD-CP-ATR-071 } \\
\text { REV-0 } \\
\text { PAGE 27 }\end{array}$ \\
\hline
\end{tabular}

\subsection{ATP ACCEPTANCE}

Any equipment non-conformance or anomalies will be listed on the Exceptions List.

Upon test completion and acceptance, the Cognizant Engineer will prepare an Acceptance Test Report (ATR) from the original ATP with field entries and transmit it to Central Files via Engineering Data Transmittal (EDT).

The undersigned concur that the ATP was completed successfully. The Honeywell Modular Automation System (MAS) was tested and operates within acceptable parameters.

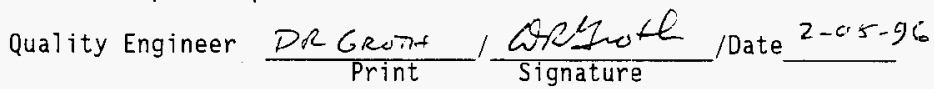

Cognizant Engineer ws Lewis $\frac{\text { Whecuri }}{\text { Print }}$ Date $2 / 2 / 96$

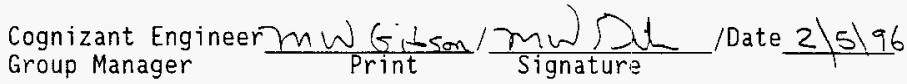




\begin{tabular}{|l|l|l|}
\hline $\begin{array}{l}\text { ACCEPTANCE TEST } \\
\text { PROCEDURE }\end{array}$ & $\begin{array}{r}\text { HONEYWELL MODULAR AUTOMATION } \\
\text { SYSTEM }\end{array}$ & $\begin{array}{l}\text { WHC-SD-CP-ATR-07I } \\
\text { REV-0 15E } \\
\text { PAGE 22-OF } 33250 F 36\end{array}$ \\
\hline
\end{tabular}

APPENDIX A

FIGURES 


\begin{tabular}{|l|r|l|}
\hline $\begin{array}{l}\text { ACCEPTANCE TEST } \\
\text { PROCEOURE }\end{array}$ & $\begin{array}{r}\text { HONEYWELL MODULAR AUTOMATION } \\
\text { SYSTEM }\end{array}$ & $\begin{array}{l}\text { WHC-SD-CP-ATR-071 } \\
\text { REV-0 } \\
\text { PAGE 23 ST 35 260F 36 }\end{array}$ \\
\hline
\end{tabular}

Figure 1 - Honeywell Modular Automation System (MAS)

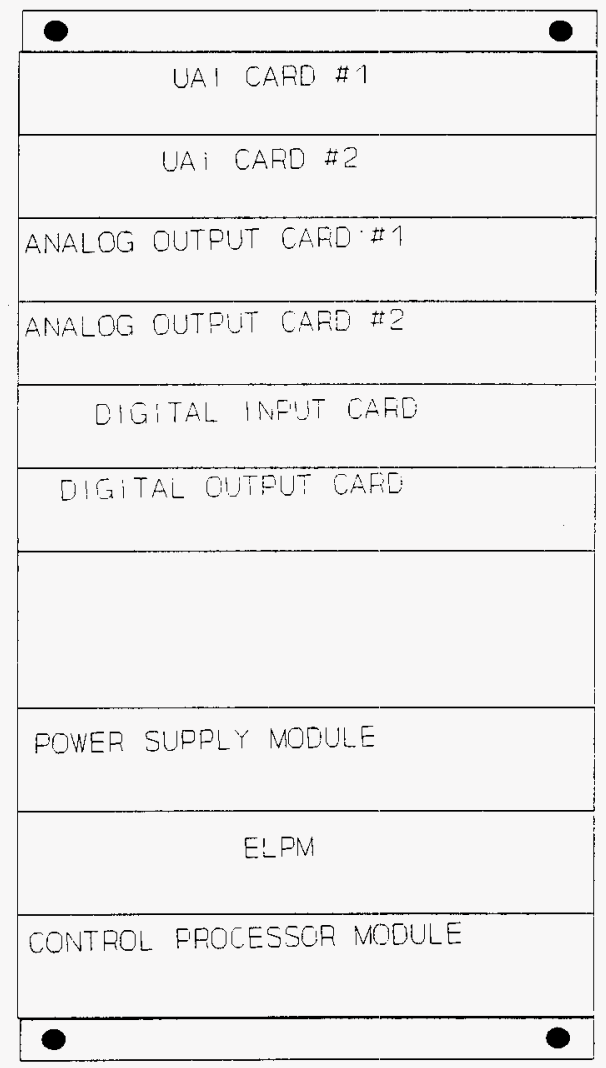




\begin{tabular}{|l|r|l|}
\hline $\begin{array}{l}\text { ACCEPTANCE TEST } \\
\text { PROCEDURE }\end{array}$ & HONEYWELL MODULAR AUTOMATION \\
& SYSTEM & $\begin{array}{l}\text { WHC-SD-CP-ATR-071 } \\
\text { REV-0 } \\
\text { PAGE 24 TR } 3327 \text { OF 36 }\end{array}$ \\
\hline
\end{tabular}

Figure 2 - Digital Input Test Box

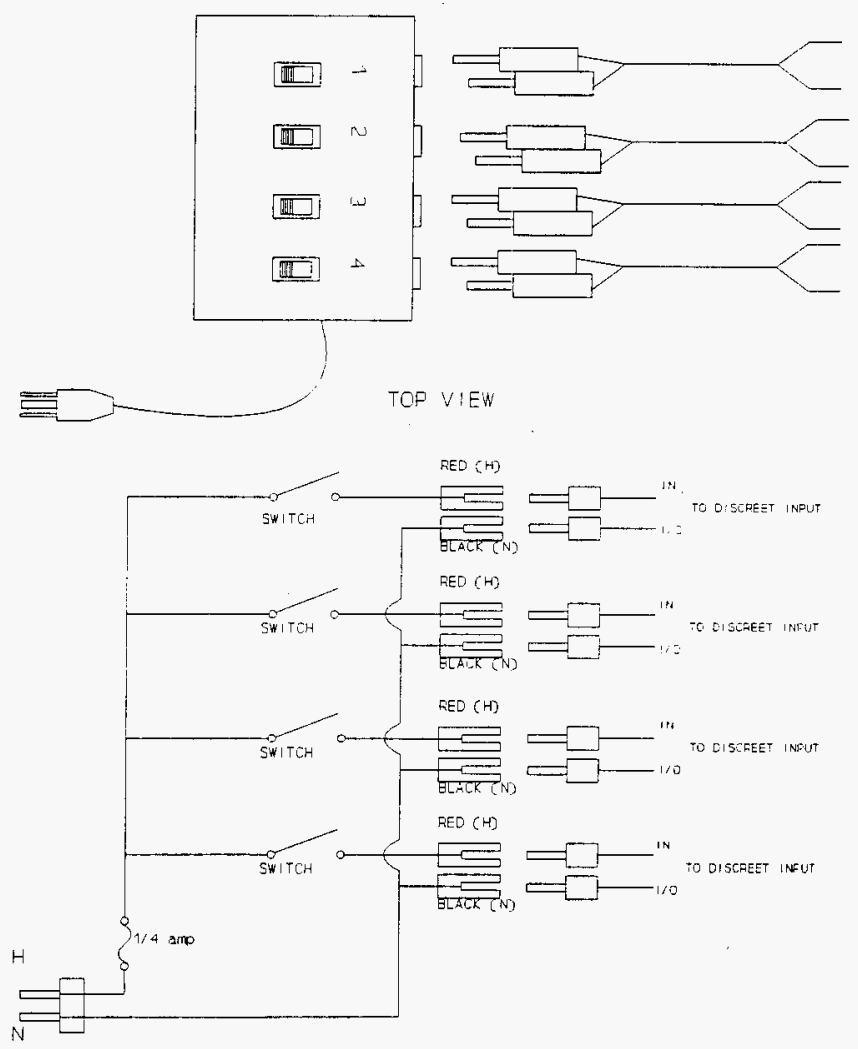




\begin{tabular}{|l|c|l|}
\hline ACCEPTANCE TEST & HONEYWELL MODULAR AUTOMATION \\
PROCEDURE & $\begin{array}{l}\text { WHC-SD-CP-ATR-071 } \\
\text { REV-0 } \\
\text { PAGE 25-OF } 3328 \text { OF 36 }\end{array}$ \\
\hline
\end{tabular}

Figure 3 - Analog Input Module Connection Schematic

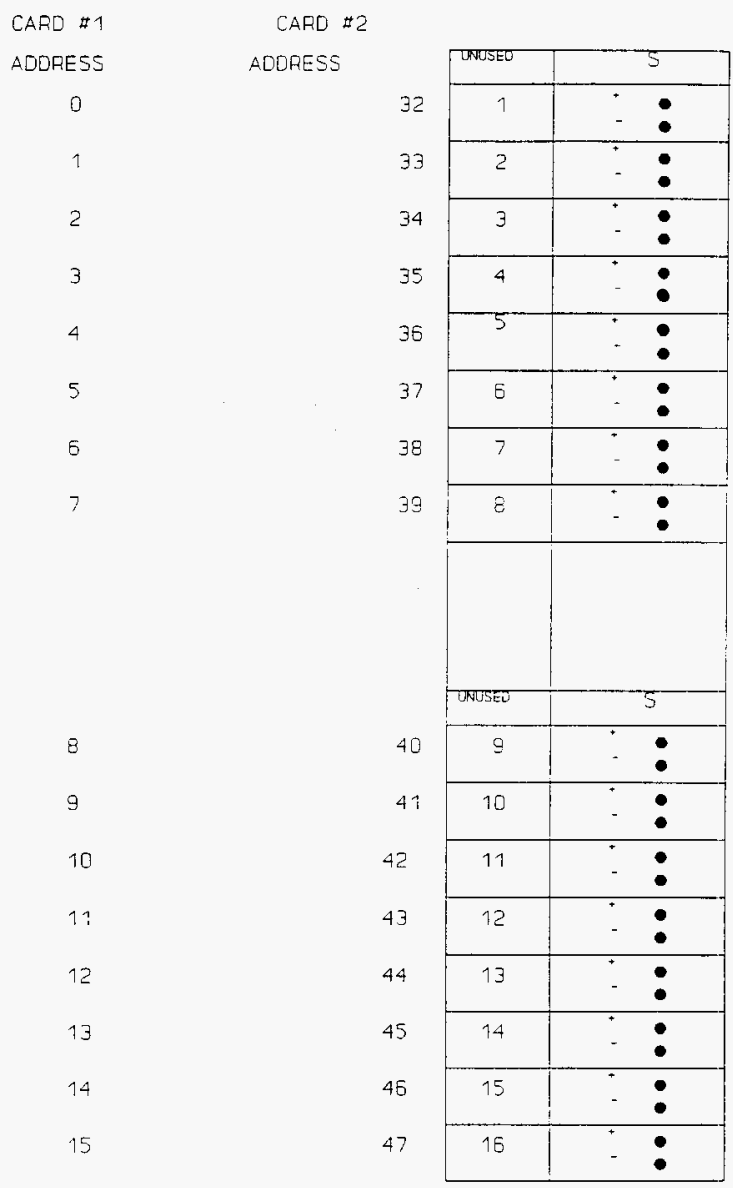




\begin{tabular}{|c|c|c|}
\hline $\begin{array}{l}\text { ACCEPTANCE TEST } \\
\text { PROCEDURE }\end{array}$ & $\begin{array}{l}\text { HONEYWELL MODULAR AUTOMATION } \\
\text { SYSTEM }\end{array}$ & $\begin{array}{l}\text { WHC-SD-CP-ATR-071 } \\
\text { REV-0 } \\
\text { PAGE 2G- कf } 329 \text { of } 36\end{array}$ \\
\hline
\end{tabular}

Figure 4 - Analog Output Module Connection Schematic: CARD \#1 CARO $\# 2$

AODRESS ADORESS

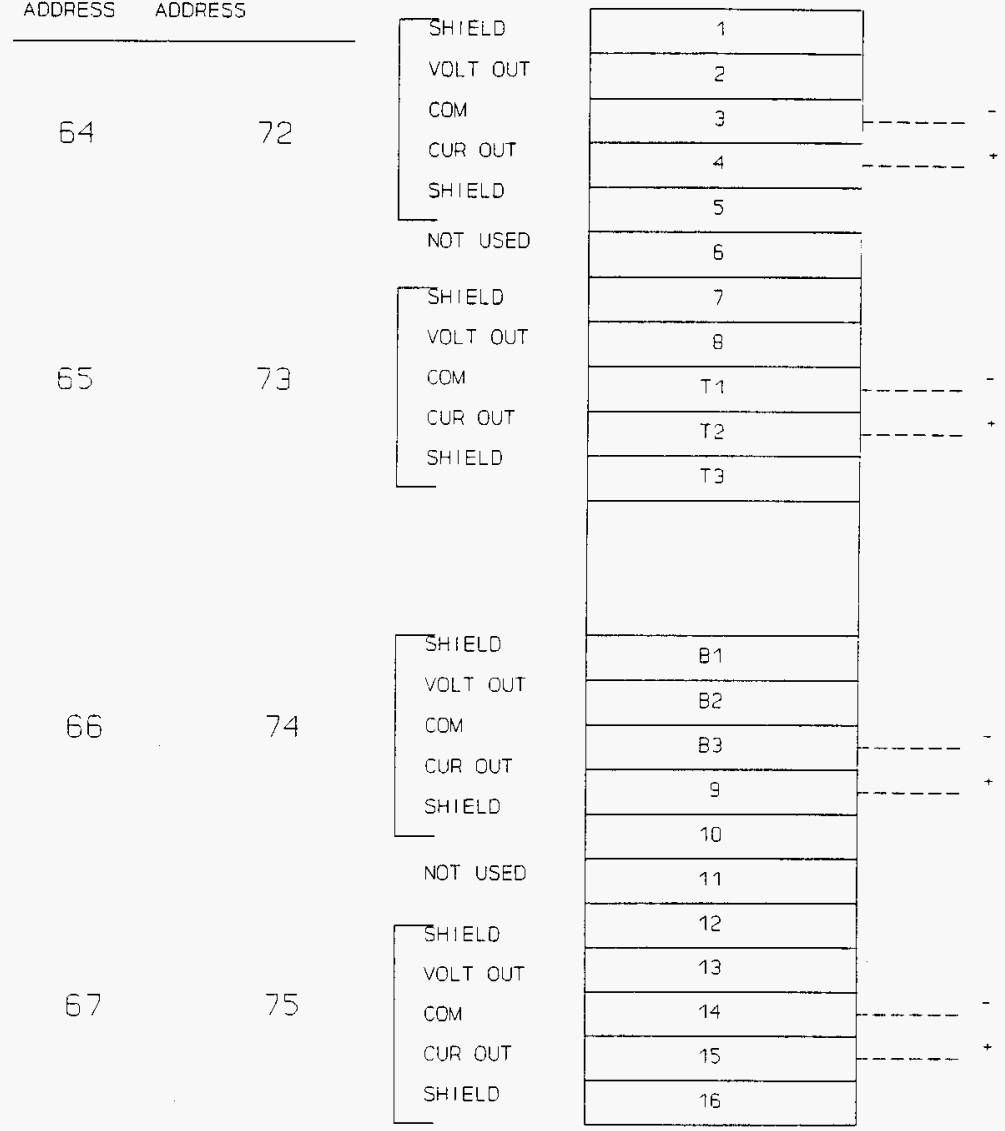




\begin{tabular}{|l|r|l|}
\hline $\begin{array}{l}\text { ACCEPTANCE TEST } \\
\text { PROCEDURE }\end{array}$ & $\begin{array}{r}\text { HONEYWELL MODULAR AUTOMATION } \\
\text { SYSTEM }\end{array}$ & $\begin{array}{l}\text { WHC-SD-CP-ATR-071 } \\
\text { REV-0 14T } \\
\text { PAGE 27 OAF } 3330 \text { of 36 } 36\end{array}$ \\
\hline
\end{tabular}

Figure 5 - Digital Input Module Connection Schematic

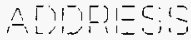

80
81
82
83

$\pm 1$

85

É

87

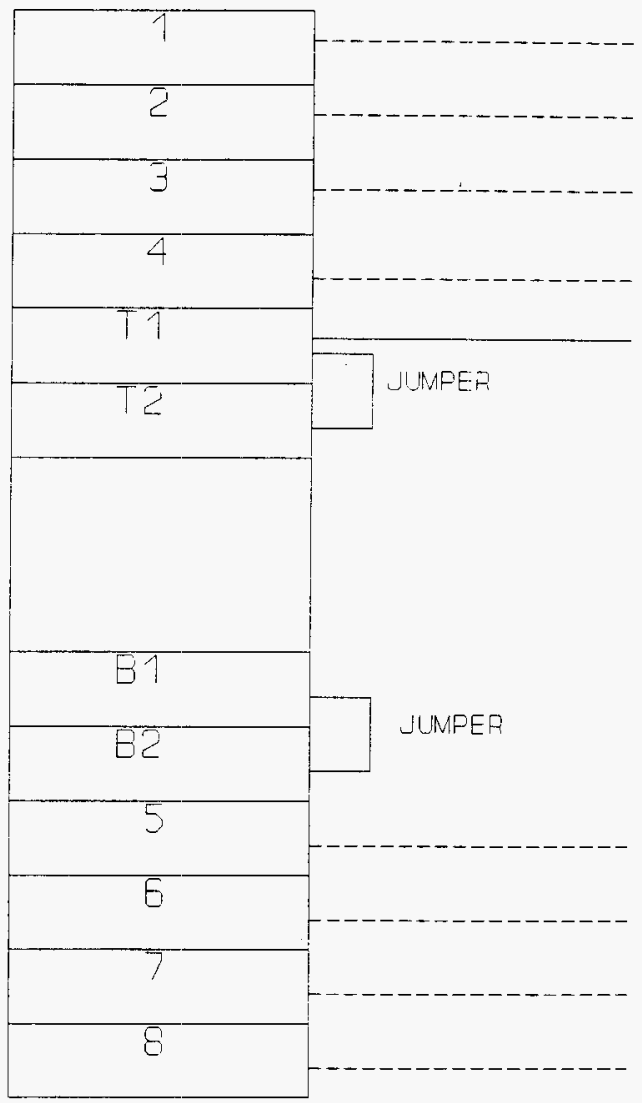




\begin{tabular}{|c|c|c|}
\hline $\begin{array}{l}\text { ACCEPTANCE TEST } \\
\text { PROCEDURE }\end{array}$ & $\begin{array}{c}\text { HONEYWELL MODULAR AUTOMATION } \\
\text { SYSTEM }\end{array}$ & $\begin{array}{l}\text { WHC-SD-LP-ATR-071 } \\
\text { REV-0 WTe } \\
\text { PAGE ZQ OF } 3331 \text { of } 36\end{array}$ \\
\hline
\end{tabular}

Figure 6 - Digital Output Module Connection Schematic

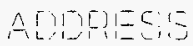

88
69
90
91

Ijo

93

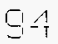

95

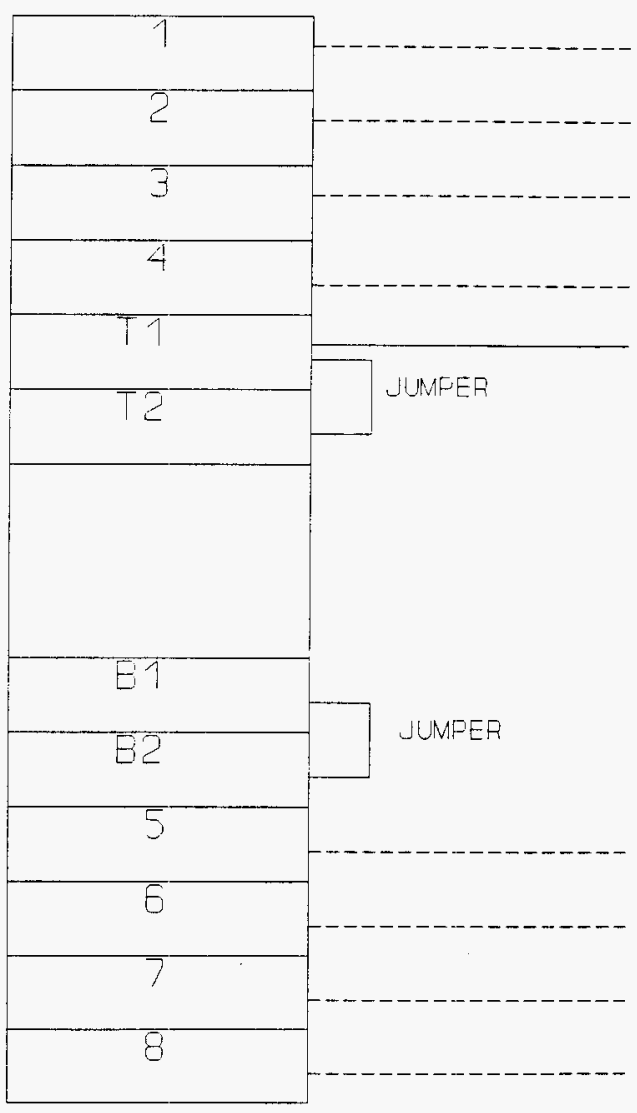




\begin{tabular}{|l|l|l|}
\hline $\begin{array}{l}\text { ACCEPTANCE TEST } \\
\text { PROCEDURE }\end{array}$ & $\begin{array}{r}\text { HONEYWELL MODULAR AUTOMATION } \\
\text { SYSTEM }\end{array}$ & $\begin{array}{l}\text { WHC-SD-CP-ATR-071 } \\
\text { REV-0 } \\
\text { PAGE Z9 }\end{array}$ \\
\hline
\end{tabular}

APPENDIX B

TEST DATA SHEETS 


\begin{tabular}{|l|r|l|}
\hline $\begin{array}{l}\text { ACCEPTANCE TEST } \\
\text { PROCEDURE }\end{array}$ & $\begin{array}{r}\text { HONEYWELL MODULAR AUTOMATION } \\
\text { SYSTEM }\end{array}$ & $\begin{array}{l}\text { WHC-SD-CP-ATR-071 } \\
\text { REV-0 whe } \\
\text { PAGE 30t-33 33 of 36 } 36\end{array}$ \\
\hline
\end{tabular}

Data Sheet 1 - HA-2OMB Temperature Inputs

Page 1 of 2

\begin{tabular}{|c|c|c|c|}
\hline STEP & ADQRESS & INPUT & DISPLAY \\
\hline \multirow[t]{3}{*}{8.3 .1} & \multirow[t]{3}{*}{0} & $25 \pm 0.2{ }^{\circ} \mathrm{C}$ & 25 \\
\hline & & $200 \pm 0.2{ }^{\circ} \mathrm{C}$ & 200 \\
\hline & & $1000 \pm 0.2{ }^{\circ} \mathrm{C}$ & 1000 \\
\hline \multirow[t]{3}{*}{8.3 .2} & \multirow[t]{3}{*}{1} & $25 \pm 0.2^{\circ} \mathrm{C}$ & $-2425^{2-16}$ \\
\hline & & $200 \pm 0.2^{\circ} \mathrm{C}$ & $20 x$ \\
\hline & & $1000 \pm 0.2^{\circ} \mathrm{C}$ & 1000 \\
\hline \multirow[t]{3}{*}{8.3 .3} & \multirow[t]{3}{*}{9} & $25 \pm 0.2{ }^{\circ} \mathrm{C}$ & 25 \\
\hline & & $200 \pm 0.2^{\circ} \mathrm{C}$ & 199.8 \\
\hline & & $1000 \pm 0.2^{\circ} \mathrm{C}$ & 1000 \\
\hline \multirow[t]{3}{*}{8.4 .1} & \multirow[t]{3}{*}{2} & $25 \pm 0.2{ }^{\circ} \mathrm{C}$ & 25.1 \\
\hline & & $200 \pm 0.2^{\circ} \mathrm{C}$ & 199.6 \\
\hline & & $1000 \pm 0.2^{\circ} \mathrm{C}$ & 999.8 \\
\hline \multirow[t]{3}{*}{8.4 .2} & \multirow[t]{3}{*}{3} & $25 \pm 0.2^{\circ} \mathrm{C}$ & $24.724,6$ \\
\hline & & $200 \pm 0.2{ }^{\circ} \mathrm{C}$ & 199.9 \\
\hline & & $1000 \pm 0.2^{\circ} \mathrm{C}$ & 999.5 \\
\hline \multirow[t]{3}{*}{8.4 .3} & \multirow[t]{3}{*}{10} & $25 \pm 0.2^{\circ} \mathrm{C}$ & 24.6 \\
\hline & & $200 \pm 0.2{ }^{\circ} \mathrm{C}$ & 199.6 \\
\hline & & $1000 \pm 0.2^{\circ} \mathrm{C}$. & 999.2 \\
\hline \multirow[t]{3}{*}{8.5 .1} & \multirow[t]{3}{*}{4} & $25 \pm 0.2{ }^{\circ} \mathrm{C}$ & 24.5 \\
\hline & & $200 \pm 0.2{ }^{\circ} \mathrm{C}$ & 199.8 \\
\hline & & $1000 \pm 0.2{ }^{\circ} \mathrm{C}$ & 999.5 \\
\hline \multirow[t]{3}{*}{8.5 .2} & \multirow[t]{3}{*}{5} & $25 \pm 0.2{ }^{\circ} \mathrm{C}$ & 24.8 \\
\hline & & $200 \pm 0.2^{\circ} \mathrm{C}$ & 199.6 \\
\hline & & $1000 \pm 0.2^{\circ} \mathrm{C}$ & 999.8 \\
\hline
\end{tabular}

NOTE - The display reading should be $\pm 0.5^{\circ} \mathrm{C}$ of the input value.

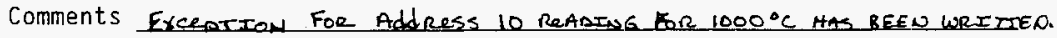




\begin{tabular}{|c|c|c|}
\hline $\begin{array}{l}\text { ACCEPTANCE TEST } \\
\text { PROCEDURE }\end{array}$ & $\begin{array}{c}\text { HONEYWELL MODULAR AUTOMATION } \\
\text { SYSTEM }\end{array}$ & $\begin{array}{l}\text { WHC-SD-CP-ATR-071 } \\
\text { REV-0 } \\
\text { PAGE 31 Qf - } 3334 \text { of } 36\end{array}$ \\
\hline
\end{tabular}

Data Sheet 1 - HA-20MB Temperature Inputs Page 2 of 2

\begin{tabular}{|c|c|c|c|}
\hline STEP & ADDRESS & INPUT & DISPLAY \\
\hline \multirow[t]{3}{*}{8.5 .3} & \multirow[t]{3}{*}{11} & $25 \pm 0.2{ }^{\circ} \mathrm{C}$ & 24.5 \\
\hline & & $200 \pm 0.2{ }^{\circ} \mathrm{C}$ & 199.7 \\
\hline & & $1000 \pm 0.2^{\circ} \mathrm{C}$ & 999.5 \\
\hline \multirow[t]{3}{*}{8.6 .1} & \multirow[t]{3}{*}{6} & $25 \pm 0.2{ }^{\circ} \mathrm{C}$ & 25.2 \\
\hline & & $75 \pm 0.2{ }^{\circ} \mathrm{C}$ & 74.9 \\
\hline & & $100 \pm 0.2^{\circ} \mathrm{C}$ & 99.7 \\
\hline \multirow[t]{3}{*}{8.6 .2} & \multirow[t]{3}{*}{7} & $25 \pm 0.2{ }^{\circ} \mathrm{C}$ & 24.5 \\
\hline & & $75 \pm 0.2{ }^{\circ} \mathrm{C}$ & 74.9 \\
\hline & & $100 \pm 0.2{ }^{\circ} \mathrm{C}$ & 98.7 \\
\hline \multirow[t]{3}{*}{8.6 .3} & \multirow[t]{3}{*}{8} & $25 \pm 0.2^{\circ} \mathrm{C}$ & 24.0 \\
\hline & & $75 \pm 0.2^{\circ} \mathrm{C}$ & 74.5 \\
\hline & & $100 \pm 0.2^{\circ} \mathrm{C}$ & 99.5 \\
\hline
\end{tabular}

NOTE - The display reading should be $\pm 0.5^{\circ} \mathrm{C}$ of the input value.

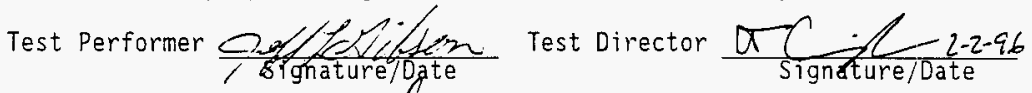
Quality control Traeflinature/Date $2 / 1 / 6$

Comments EXceptEON HAS BEEN WRITTEN FOR LOW DISPLAY RCAOING ON THIS DATA SHEET. 


\begin{tabular}{|l|r|l|}
\hline $\begin{array}{l}\text { ACCEPTANCE TEST } \\
\text { PROCEDURE }\end{array}$ & HONEYWELL MODULAR AUTOMATION \\
SYSTEM & $\begin{array}{l}\text { WHC-SD-CP-ATR-071 } \\
\text { REV-0 } \\
\text { PAGE 32 wE } 3535 \text { OF 36 } 36\end{array}$ \\
\hline
\end{tabular}

\section{Data Sheet 2 - HA-21I Temperature Inputs Page 1 of 2}

\begin{tabular}{|c|c|c|c|}
\hline STEP & ADDRESS & INPUT & DISPLAY \\
\hline \multirow[t]{3}{*}{8.7 .1} & \multirow[t]{3}{*}{32} & $25 \pm 0.2^{\circ} \mathrm{C}$ & 25.1 \\
\hline & & $200 \pm 0.2{ }^{\circ} \mathrm{C}$ & 199.8 \\
\hline & & $1000 \pm 0.2^{\circ} \mathrm{C}$ & 999.5 \\
\hline \multirow[t]{3}{*}{8.7 .2} & \multirow[t]{3}{*}{33} & $25 \pm 0.2^{\circ} \mathrm{C}$ & $24+5 \quad 24.5$ \\
\hline & & $200 \pm 0.2{ }^{\circ} \mathrm{C}$ & 199.5 \\
\hline & & $1000 \pm 0.2{ }^{\circ} \mathrm{C}$ & 999.3 \\
\hline \multirow[t]{3}{*}{8.7 .3} & \multirow[t]{3}{*}{41} & $25 \pm 0.2{ }^{\circ} \mathrm{C}$ & 23.8 \\
\hline & & $200 \pm 0.2{ }^{\circ} \mathrm{C}$ & $19 q .1$ \\
\hline & & $1000 \pm 0.2^{\circ} \mathrm{C}$ & 998.5 \\
\hline \multirow[t]{3}{*}{8.8 .1} & \multirow[t]{3}{*}{34} & $25 \pm 0.2^{\circ} \mathrm{C}$ & 24.5 \\
\hline & & $200 \pm 0.2^{\circ} \mathrm{C}$ & 200.0 \\
\hline & & $1000 \pm 0.2^{\circ} \mathrm{C}$ & 999.7 \\
\hline \multirow[t]{3}{*}{8.8 .2} & \multirow[t]{3}{*}{35} & $25 \pm 0.2{ }^{\circ} \mathrm{C}$ & 25.1 \\
\hline & & $200 \pm 0.2{ }^{\circ} \mathrm{C}$ & 200.3 \\
\hline & & $1000 \pm 0.2^{\circ} \mathrm{C}$ & 1000.0 \\
\hline \multirow[t]{3}{*}{8.8 .3} & \multirow[t]{3}{*}{42} & $25 \pm 0.2^{\circ} \mathrm{C}$ & 324.0 \\
\hline & & $200 \pm 0.2{ }^{\circ} \mathrm{C}$ & 199.1 \\
\hline & & $1000 \pm 0.2^{\circ} \mathrm{C}$ & 998.4 \\
\hline \multirow[t]{3}{*}{8.9 .1} & \multirow[t]{3}{*}{36} & $25 \pm 0.2^{\circ} \mathrm{C}$ & 24.7 \\
\hline & & $200 \pm 0.2^{\circ} \mathrm{C}$ & 199.7 \\
\hline & & $1000 \pm 0.2^{\circ} \mathrm{C}$ & 999.7 \\
\hline \multirow[t]{3}{*}{8.9 .2} & \multirow[t]{3}{*}{37} & $25 \pm 0.2^{\circ} \mathrm{C}$ & 24.1 \\
\hline & & $200 \pm 0.2^{\circ} \mathrm{C}$ & 199.5 \\
\hline & & $1000 \pm 0.2^{\circ} \mathrm{C}$ & 998.9 \\
\hline
\end{tabular}

NOTE - The display reading should be $\pm 0.5^{\circ} \mathrm{C}$ of the input value.

Comments 


\begin{tabular}{|l|r|l|}
\hline \hline $\begin{array}{l}\text { ACCEPTANCE TEST } \\
\text { PROCEDURE }\end{array}$ & HONEYWELL MODULAR AUTOMATION \\
SYSTEM & $\begin{array}{l}\text { WHC-SD-CP-ATR-071 } \\
\text { REV-0 } \\
\text { PAGE } 33 \text { CR } 33 \text { 36 OF 36 } 36\end{array}$ \\
\hline
\end{tabular}

Data Sheet 1 - HA-21I Temperature Inputs Page 2 of 2

\begin{tabular}{|c|c|c|c|}
\hline STEP & ADDRESS & INPUT & DISPLAY \\
\hline \multirow[t]{3}{*}{8.9 .3} & \multirow[t]{3}{*}{43} & $25 \pm 0.2{ }^{\circ} \mathrm{C}$ & 24.3 \\
\hline & & $200 \pm 0.2^{\circ} \mathrm{C}$ & 198.8 \\
\hline & & $1000 \pm 0.2^{\circ} \mathrm{C}$ & 998.2 \\
\hline \multirow[t]{3}{*}{8.10 .1} & \multirow[t]{3}{*}{38} & $25 \pm 0.2{ }^{\circ} \mathrm{C}$ & 24.1 \\
\hline & & $75 \pm 0.2{ }^{\circ} \mathrm{C}$ & 74.3 \\
\hline & & $100 \pm 0.2^{\circ} \mathrm{C}$ & 99.1 \\
\hline \multirow[t]{3}{*}{8.10 .2} & \multirow[t]{3}{*}{39} & $25 \pm 0.2{ }^{\circ} \mathrm{C}$ & 25.0 \\
\hline & & $75 \pm 0.2{ }^{\circ} \mathrm{C}$ & 7.5 .2 \\
\hline & & $100 \pm 0.2^{\circ} \mathrm{C}$ & 99.8 \\
\hline \multirow[t]{3}{*}{8.10 .3} & \multirow[t]{3}{*}{40} & $25 \pm 0.2{ }^{\circ} \mathrm{C}$ & 24.6 \\
\hline & & $75 \pm 0.2{ }^{\circ} \mathrm{C}$ & $74^{7} 75.1$ \\
\hline & & $100 \pm 0.2{ }^{\circ} \mathrm{C}$ & 99.9 \\
\hline
\end{tabular}

NOTE - The display reading shouTd be $\pm 0.5^{\circ} \mathrm{C}$ of the input vaTue.

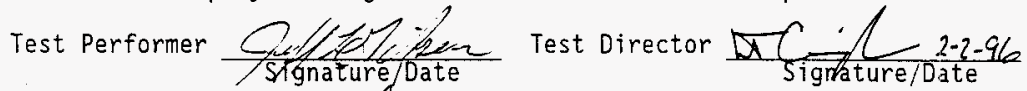
Quality control Tyelefforefifec

Comments Exceotion 1 HAS BFEN WRITIEN FOR THE DISPNY RaADTWGS ON TITS OATA SHEET THAT DEDNOT MEET $=0.5^{\circ} \mathrm{C}$ EE TNPUT VALUE, 